\title{
Anatomical and Histological Components of the Bilaminar Zone of the Temporomandibular Joint. A Narrative Review
}

\author{
Componentes Anatómicos e Histológicos de la Zona Bilaminar \\ de la Articulación Temporomandibular. Una Revisión Narrativa
}

Farfán Constanza1 ${ }^{1,2,3}$; Quidel Bryan4; Borie-Echevarría Evelyn \& Fuentes Ramón ${ }^{1,3}$

FARFÁN, C.; QUIDEL, B.; BORIE-ECHEVARRÍA, E. \& FUENTES, R. Anatomical and histological components of the bilaminar zone of the temporomandibular joint. A narrative review. Int. J. Morphol., 39(2):477-483, 2021.

SUMMARY: One of the structures which contributes to the correct functioning of the Temporomandibular Joint (TMJ) is the Articular Disc (AD). Viewed in sagittal section, the AD is divided into four zones, the last is the Bilaminar Zone (BZ). The BZ is essential for keeping the $\mathrm{AD}$ in its superior position and for retracting the $\mathrm{AD}$ to posterior in the maximum aperture position. Its composition and the disposition of its components is unclear. The object of this narrative review is to update concepts on the anatomy of the BZ, with its variations, histological components, vascularization and innervation. The following databases were reviewed: PUBMED, SCOPUS, EMBASE, WEB OF SCIENCE, SciELO and LILACS. Only studies in human beings without alterations to the TMJ, using dissection in cadavers or radiography in live subjects, were included. Systematic reviews, letters to the editor, technical articles and experimental or quasi-experimental studies in animals were excluded. This review included a total of 24 articles which corresponded to the proposed research object. Our results describe the morphology of the BZ, its anatomical relations and possible variations, its histological components, types of fibre and distribution percentages; the latter are discussed in the literature, but no consensus exists. This is not the case for the vascularization and innervation of the BZ; all authors analyzed agree on these points, with just one author adding two possible arteries that may play a part in irrigation. Furthermore, a large number of authors recognize the discomalleolar ligament and its close relation with the BZ.

KEY WORDS: Temporomandibular joint; Anatomy; Bilaminar zone; Retrodiscal zone; Histology.

\section{INTRODUCTION}

The TMJ is considered one of the most complex structures of the organism (Grau et al., 2005). The composition, morphology and anatomical terminology of its structures have been described and discussed in the literature (Fuentes et al., 2016a,b; Eder et al., 2018). Of these structures, the $\mathrm{AD}$ has received great attention due to its anatomical relations with neighbouring structures and its importance in the correct functioning of the TMJ (Eder et $a l$.). In sagittal section, it is divided into four zones: the anterior zone, the middle or working zone, the posterior zone and the BZ (Matamala et al., 2006), also called the retrodiscal tissue, posterior insertion (Okeson, 2013), retrodiscal pad (Ballesteros \& León-S, 1999), retrodiscal zone (Matamala et al.) or posterior segment of the joint capsule (PS-JC) of the TMJ (Mérida Velasco et al., 1997). Some authors even describe the $\mathrm{BZ}$ as a posterior ligament (Mackinnon \& Morris, 1993; Pertes \& Gross, 2005); Fuentes \& Ottone (2017) proposed that the term "Posterior Ligament" should be added to the international anatomical terminology to identify this structure, in order to reach a common anatomical terminology for all researchers and clinicians who work on the TMJ.

The BZ is located within the posterior margin of the $\mathrm{AD}$ and faces the posterior wall of the mandibular fossa and the neck of the mandibular condyle (MC); it may even fuse with the joint capsule (Fuentes et al., 2016a,b), It is divided into a "superior retrodiscal lamina" or "temporal region" facing the temporal bone, composed of collagen and elastic fibers; an "inferior retrodiscal lamina" or "condylar region"

\footnotetext{
${ }^{1}$ Dental School, Research Centre for Dental Sciences (CICO), Universidad de La Frontera, Temuco, Chile.

${ }^{2}$ Department of Integral Adults Dentistry, Dental School, Universidad de La Frontera, Temuco, Chile.

${ }^{3}$ Universidad Adventista de Chile, Chillán, Chile.

${ }^{4}$ Undergraduate student, Dental School, Universidad de La Frontera, Temuco, Chile.

${ }^{5}$ Dental School, Facultad de Ciencias, Universidad Mayor, Temuco, Chile.
} 
composed of collagen fibers; and a highly vascularized and innervated region where the rest of the retrodiscal tissue is joined to a large venous plexus, which fills with blood when the MC is displaced to anterior (Gómez \& Campos, 2009; Okeson; Coombs et al., 2017).

In histological terms, the BZ consists of a system of fibroelastic tissues in which we find collagen fibers, elastic fibers, blood and lymph vessels, nerves and a long venous plexus which gives the BZ a spongy appearance, accompanied by connective and adipose tissue which fill up the zone (Wilkinson \& Crowley, 1994; Benigno et al., 2001). Irrigation is provided by the anterior branches of the posterior auricular artery (Mérida-Velasco et al., 2007) and the venous spaces consist of a large retrodiscal venous plexus that drains into the superficial temporal veins and the pterygoid venous plexus. The sensitive innervation is provided by the auriculotemporal nerve, which extends through the posterior region of the TMJ (Fuentes et al., 2016a,b).

With respect to the functions of the BZ, the inferior portion is essential for holding the $\mathrm{AD}$ in its superior position; it is also the only structure able to retract the $\mathrm{AD}$ to posterior on the $\mathrm{MC}$ to produce the highest levels of retractive force in the maximum aperture position (Leonardi et al., 2012; Okeson). It has been reported that the principal inflammatory and degenerative changes in the TMJ occur mainly in the insertion zone posterior of the AD (Paegle et al., 2002). In non-pathological states, the BZ is considered to be one of the functional anatomical elements that help to establish the centric relation (Farfán et al., 2020).

Despite the many attempts to describe the biomechanics and morphological disposition of the components of the BZ, this structure is still little understood, and regional physiological variations in its traction properties and fibre organization have not been determined (Coombs et al.). The object of this narrative review is to update concepts on the anatomy of the BZ, with its variations, histological components, vascularization and innervation.

\section{MATERIAL AND METHOD}

A literature review was carried out following the guidelines of the PRISMA declaration (Preferred Reporting Items for Systematic reviews and Meta-Analyses) (Urrútia $\&$ Bonfill, 2010). The electronic databases consulted were PUBMED, SCOPUS, EMBASE, WEB OF SCIENCE, SciELO and LILACS. The search was carried out during the months of May and June 2020 by two independent reviewers.
The following search terms were used to identify all the publications related with the research object: "Temporomandibular Joint", “TMJ”, "Bilaminar zone", "Retrodiscal pad", "Elastic Tissue", "Collagen fibers", "Blood vessels", "Blood supply", "Vascularization", "Venous drainage", "Innervation", "Neural elements" and "Anatomy". These terms were combined with Boolean operators "AND" and "OR", accompanied by the use of MeSH terms.

No date limits were set for the search; articles in English, Spanish and Portuguese were included. The reviewers made the first selection of articles based on reading of the titles and abstracts. Full text analysis was decided following the eligibility criteria established, selecting potentially relevant studies. All disagreements between the two reviewers on the relevance and inclusion of the studies were discussed until consensus was reached; persistent disagreements were resolved in the same way with a third reviewer.

Eligibility criteria. Studies were included which contribute to description of the innervation, vascularization, and anatomical and histological characteristics of the BZ of the TMJ, and articles that describe possible anatomical variations of the BZ. Only studies in humans without alterations to the TMJ, using dissection in cadavers or radiography in live subjects, were included. Systematic reviews, letters to the editor, technical articles and experimental or quasi-experimental studies in animals were excluded.

\section{RESULTS}

The searches in the different databases identified a total of 845 articles. After elimination of duplicates, 514 potentially eligible articles remained; the titles and abstracts were read and those articles which were irrelevant for the study object were eliminated. By this process 104 articles were selected for full text reading and selection according to all our eligibility criteria. Eighty-two articles were excluded, leaving a total of 22; to these were added 2 articles identified from other sources, giving a total sample of 24 articles as shown in the flow chart (Fig. 1).

Participants: All the articles selected were studies carried out in cadavers; only one included computerized tomography images of live subjects. The analysis methods were dissection, optical microscopy, polarised light microscopy, sweep electron microscopy and digital imaging.

Of the 24 articles describing the BZ in cadavers, 20 were of adults, two of foetuses aged between 3.5 and 10 


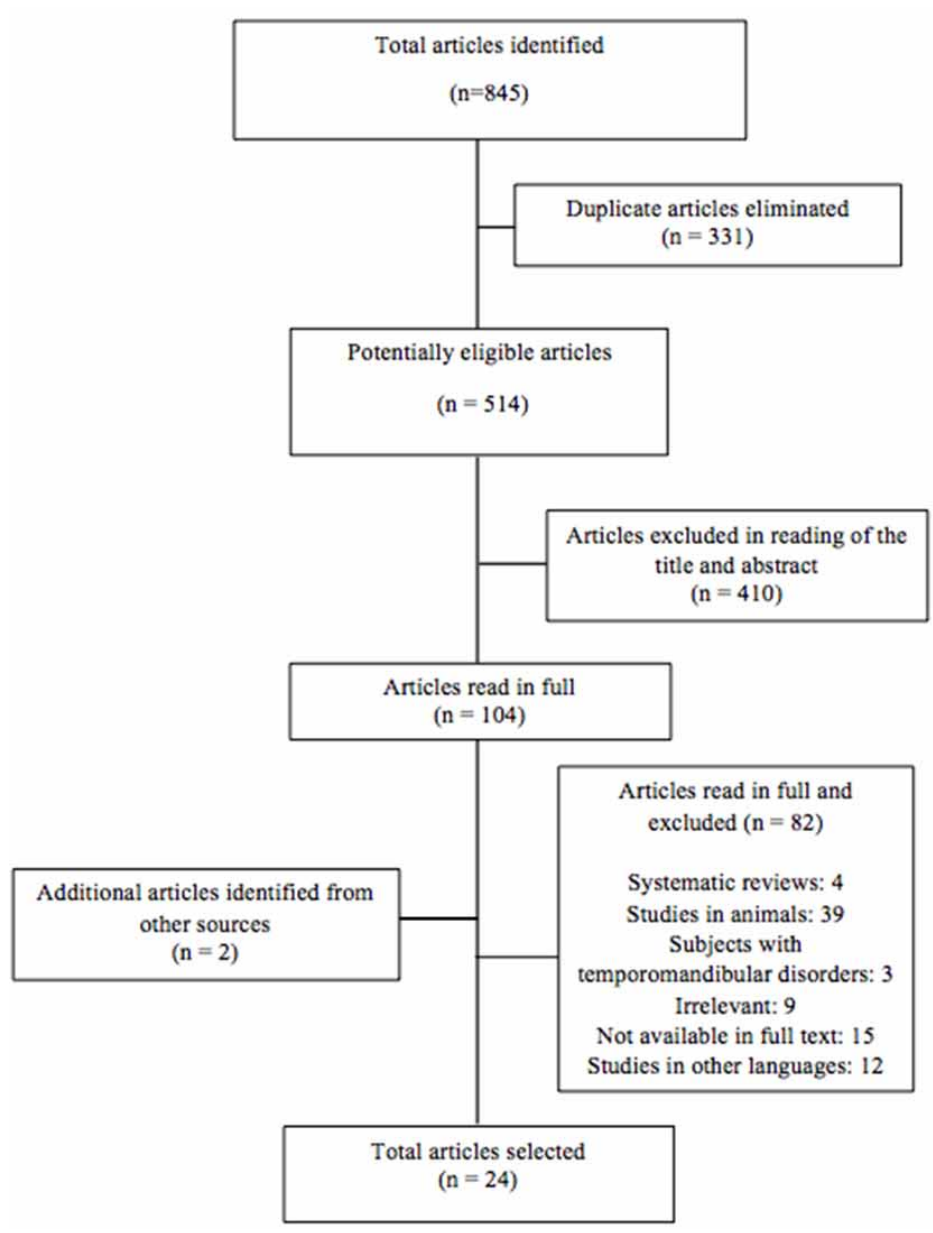

Fig. 1. Flow diagram of scientific search.

months, one study included both adult cadavers and foetuses and one did not specify the age of the sample. Fifteen studies assessed the BZ in both sexes, two studies only in men, one only in women and six studies did not report the sex.

Principal results of the studies: In line with our object, we were able to identify studies describing the anatomy of the BZ, its histological components, irrigation and innervation, and variations in its anatomical relations.

Anatomy of the bilaminar zone. The BZ is rhomboid in shape; the fibers of the posterior segment of the joint capsule form the base, the superior and inferior laminae form the sides and the posterior zone of the AD forms the apex (Wilkinson \& Crowley). Studies which describe the anatomy of the BZ distinguish the courses of the superior and inferior laminae (Table I), and report that the two laminae are separated by a vascular intermediate zone (Wilkinson \& Crowley ; Mérida Velasco et al., 1997; Benigno et al.; Mérida-Velasco et al., 2007). Other authors, in contrast, state that this zone is not organised into a superior and an inferior lamina, and that the name BZ is incorrect, since histologically the fibers of the superficial layer of the retrodiscal area are arranged principally from medial to lateral (Kino et al., 1993; Shiraishi et al., 1995).

The medial portion of the BZ consists of abundant elastic fibers originating in the petrotympanic fissure. Some authors call this zone the "discomalleolar ligament" (Mérida-Velasco et al., 2012; Anastasi et al., 2020); it is triangular in shape with its base in the posterior zone of the $\mathrm{AD}$ and its apex towards the mandibular fossa in the petrotympanic fissure (Mérida-Velasco et al., 2007; Mérida-Velasco et al., 2012). Anastasi et al. studied the morphology of this ligament in a sample of 5 cadavers and 40 computerised tomographies, identifying the shape as triangular, rectangular and curved in $90 \%, 5 \%$ and $5 \%$ of the sample respectively; they also reported a mean area of $29 \pm$ $0.83 \mathrm{~mm} 2$ for this zone. Its insertion has been described in the posteromedial region of the joint capsule and the retrodiscal zone (Loughner et al., 1997; Anastasi et al.), in the posterior zone of the AD (Mérida-Velasco et al., 2012), the sphenomandibular ligament (Mérida Velasco et al., 1997), posterior face of the adventitia of the venous plexus and the posterior face of the MC (Kino et $a l$.$) ; it is reported to run to the tympanic cavity$ through the petrotympanic fissure at the neck of the hammer in the middle ear (Mérida Velasco et al.; Loughner et al.). A study by Arai \& Sato (2011) found that the discomalleolar ligament extended to the anterior region of the hammer in the epitympanic recess in the tympanic cavity; it also identified a connection close to but independent of the discomalleolar ligament and the anterior ligament of the hammer. In histological terms, it is formed of collagen fibers, mainly type I collagen surrounded by a few type 111 fibers, and accompanied by abundant elastic fibers in anteroposterior disposition with small zones of adipose tissue (Mérida-Velasco et al., 2012 Anastasi et al.).

The PS-JC has been described as a lamina extending from the temporal bone to the MC, separate from and independent of the BZ (Mérida Velasco et al.). However, various studies have identified this structure as part of the BZ (Schmolke, 1994; Mérida Velasco et al.; Mérida-Velasco et al., 2007, 2012). Wilkinson \& Crowley say that the PSJC extends from the tympanosquamous fissure to the neck of the $\mathrm{MC}$, below the junction of the inferior lamina of the BZ. Siéssere et al. (2004) called the PS-JC "long fibers", distinguishing a single point of insertion in the temporal bone next to the superior lamina of the BZ. 
Table I. Anatomical extensions of the BZ.

\begin{tabular}{|c|c|c|c|c|}
\hline \multirow[t]{2}{*}{ Author/year } & \multirow[t]{2}{*}{ Sample } & \multirow[t]{2}{*}{ Country } & \multicolumn{2}{|l|}{ Results } \\
\hline & & & Superior lamina & Inferior lamina \\
\hline Mérida et al., 1997 & 18 cadavers & Spain & $\begin{array}{l}\text { From the posterior zone of the } \mathrm{AD} \text { to the } \\
\text { posterior wall of the mandibular fossa. }\end{array}$ & $\begin{array}{l}\text { From the posterior zone of the AD } \\
\text { to the posterior surface of the MC. }\end{array}$ \\
\hline Mérida et al., 2007 & 20 cadavers & Spain & $\begin{array}{l}\text { From the } \mathrm{AD} \text { to the mandibular fossa, with } \\
\text { finding of reinforcement in the internal third by } \\
\text { the discomalleolar ligament. }\end{array}$ & From the $\mathrm{AD}$ to the $\mathrm{MC}$. \\
\hline $\begin{array}{l}\text { Wilkinson } \\
\text { Crowley, } 1994\end{array}$ & 8 cadavers & Australia & $\begin{array}{l}\text { From the posterior zone of the AD to the slope of } \\
\text { the mandibular fossa opposite the postglenoid } \\
\text { proc ess where it is folded over itself. }\end{array}$ & $\begin{array}{l}\text { From the posterior zone of the } \mathrm{AD} \\
\text { to the neck of the MC. }\end{array}$ \\
\hline Kino et al., 1993 & 9 cadavers & Japan & $\begin{array}{l}\text { Did not identify the presence of a s uperior } \\
\text { lamina in the BZ. }\end{array}$ & $\begin{array}{l}\text { Most of the fibres of the } \mathrm{BZ} \text { are } \\
\text { connected to the MC. }\end{array}$ \\
\hline
\end{tabular}

Histology of the bilaminar zone: Most of the studies that analyse the histological composition of the $\mathrm{BZ}$ do so by its parts: superior lamina, inferior lamina or intermediate zone (Table II).

From the fourth month of gestation, small elastic and collagen fibers can be identified in the BZ, which increase in number and thickness over time (Yang et al., 1992; Ohta et al., 1993). At this age, the superior lamina is seen to contain abundant fibroblasts with collagen fibers in formation with an undulating disposition in 2 different directions, one "posterior, superior and lateral", and the other "anterior, inferior and medial" (Yang et al.); scattered elastic fibers are also observed in anteroposterior disposition with crosswise collagen fibers (Ohta et al.). The inferior lamina, on the other hand, consists of a structure of fibrous layers which forms a network of dense fibers aligned from anterior to posterior (Yang et al.; Ohta et al.) and from medial to lateral (Yang et al.).

In adults, the $\mathrm{BZ}$ generally consists of loose connective tissue characterised by the presence of a network of collagen fibers and abundant elastic fibers covered by a synovial layer (Paegle et al.; Sakuma et al., 2003; Oyanguren

Table II. Histological composition of the BZ.

\begin{tabular}{|c|c|c|c|c|c|}
\hline Author/Year & Sample & Country & Superior lamina & $\begin{array}{c}\text { Results } \\
\text { Intermediate zone }\end{array}$ & Inferior lamina \\
\hline $\begin{array}{l}\text { Clément et al., } \\
2006\end{array}$ & 7 ca davers & France & $\begin{array}{l}\text { Composed of } 15.32 \% \pm \\
11.5 \% \text { of elastic fibres: The } \\
\text { lateral, central and medial } \\
\text { portions contaim: } 8.89 \% \pm \\
7.96 \%, 16.87 \% \pm 10.22 \% \\
\text { and } 18.22 \% \pm 13.3 \% \\
\text { respectively. }\end{array}$ & --- & $\begin{array}{l}\text { Composed of } 10.97 \% \pm \\
11.59 \% \text { of elastic fibres: } \\
\text { The lateral, central and } \\
\text { medial portions contaim: } \\
4.92 \% \pm 7.73 \%, 16.87 \% \pm \\
10.22 \% \text { and } 18.22 \% \pm \\
13.3 \% \text { respectively. }\end{array}$ \\
\hline $\begin{array}{l}\text { Benigno et al., } \\
2001\end{array}$ & 28 cadavers & Brazil & $\begin{array}{l}\text { The anterior and medial } \\
\text { regions contain thick } \\
\text { collagen fibres disposed } \\
\text { obliquely and crosswise, } \\
\text { with no specific } \\
\text { orientation. The orientation } \\
\text { of the fibres of the } \\
\text { posterior region was } \\
\text { antero-posterior. }\end{array}$ & $\begin{array}{l}\text { The medial and posterior } \\
\text { portions contain many blood } \\
\text { vessels and vascular spaces, } \\
\text { filled with loose connective } \\
\text { and adipose tissue, with few } \\
\text { collagen fibres disposed } \\
\text { antero-posterior. }\end{array}$ & $\begin{array}{l}\text { It is composed of curved } \\
\text { collagen fibres oriented in } \\
\text { an antero-posterior } \\
\text { direction. }\end{array}$ \\
\hline $\begin{array}{l}\text { Wilkinson \& } \\
\text { Crowley, } 1994\end{array}$ & 8 ca davers & Australia & $\begin{array}{l}\text { Composed of fibroelastic } \\
\text { tissue, oriented parallel to } \\
\text { the surface of the } \\
\text { mandibular fossa. }\end{array}$ & $\begin{array}{l}\text { Formed of elastic and } \\
\text { collagen fibres, blood and } \\
\text { lymph vessels, adipose tissue, } \\
\text { a large venous plexus and an } \\
\text { extended nervous supplement. }\end{array}$ & $\begin{array}{l}\text { Composed of fibroelastic } \\
\text { tissue with collagen fibres } \\
\text { oriented parallel to the } \\
\text { surface of the MC. }\end{array}$ \\
\hline $\begin{array}{l}\text { Mérida et al., } \\
1997\end{array}$ & 18 cadavers & Spain & --- & $\begin{array}{l}\text { Composed of loose } \\
\text { connective tissue and adipose } \\
\text { tissue. }\end{array}$ & --- \\
\hline
\end{tabular}


et al., 2010). Over the whole area are type I collagen fibers accompanied by fine bands of type III collagen fibers; this type I collagen also forms part of the walls of the blood vessels. Parallel to the collagen fibers, elastic fibers can be identified forming a thin layer around the walls of the vascular spaces (Benigno et al.). These elastic fibers are distributed in both the superior and the inferior lamina, and occur freely throughout the intermediate zone of the BZ (Wilkinson \& Crowley). All these characteristics of the BZ allow the remarkable range of movement of the $\mathrm{AD}$ which prevents dislocation during mandibular aperture (Siéssere et al., 2008).

Type A and B synovial cells can be identified in the synovial layer covering the BZ; they cover the retrodiscal tissue which extends to include the extra tympanic portion of the discomalleolar ligament as far as the posterior zone of the AD (Helmy et al., 1990; Mérida-Velasco et al., 2012). The BZ is made up of fibroblast cells (Helmy et al.; Paegle et al.), accompanied by abundant blood vessels (Kino et al.). Kurita et al. (1989) identified the total composition of the $\mathrm{BZ}$ as $7.7 \% \pm 1.42 \%$ fibroblasts and a total of $2.6 \% \pm 1.22$ $\%$ blood vessels per square millimeter. However, in two studies the presence of chondrocyte cells in healthy subjects was discarded (Kurita et al., 1989; Paegle et al.). Helmy et al. using histological techniques in four cadavers, observed occasional chondrocytes in one of their samples, with a variable quantity of territorial matrix close to the posterior zone of the $\mathrm{AD}$, however this finding may be related to the unknown clinical history of the cadaver.

Irrigation of the bilaminar zone. All the authors reviewed agree that the BZ is irrigated by branches of the anterior portion of the anterior tympanic artery, which courses through the connective tissue of the whole $\mathrm{BZ}$ via the intermediate zone (Mérida Velasco et al.; Benigno et al.; Mérida-Velasco et al., 2007, 2012). However, a study by Siésser et al. (2004) noted that the superficial temporal artery and the deep auricular artery also play a part in irrigation.

The arteries and arterioles of the BZ consist of extremely thick walls containing up to four layers of muscle in the tunica media. The vein walls on the other hand are thin, and the endothelial vascular sinuses are set in a matrix of loose connective and adipose tissues (Wish-Baratz et al., 1993). The BZ is morphologically different from the erectile vascular tissue found in the corpora cavernosa of the penis, since it lacks thick, muscular vein walls similar to those of the arteries and channels connecting the veins to adjacent venules and capillaries; however, the BZ can provide an active vascular mechanism which helps to fill the zone with blood during mandibular aperture (Parsons \& Boucher, 1966; Wish-Baratz et al.).
Innervation of the BZ. The BZ is innervated by one to three collateral and terminal branches of the auriculotemporal nerve which enter through the postero-external face of the TMJ (Mérida Velasco et al.; Siéssere et al., 2004; DecuadroSáenz et al., 2008; Mérida-Velasco et al., 2012).

Anatomical variations and relations. Among the many studies included, Shiraishi et al. was the only one to describe rarely mentioned structures associated with the BZ. In their dissection of 14 Japanese cadavers (13 women and 1 man), they identified a fibrous structure attached to the posterior and lateral region of the $\mathrm{BZ}$ connected to structures like the fascia of the Masseter muscle in the angle of the jaw, the capsule of the parotid gland, the lateral ligament and the periost of the ramus of the mandible, accompanied by a vein approximately $1 \mathrm{~mm}$ in diameter which originates in the venous plexus of the $\mathrm{BZ}$ and then extends branches to the retromandibular, transverse facial and superficial temporal veins. They called these structures the reticular ligament and reticular vein.

Among the anatomical relations with neighbouring structures, the authors identified parotid gland tissue in intimate relation with the BZ, either under the PS-JC (Wilkinson \& Crowley) or close to the blood vessels of the BZ (Parsons \& Boucher). However, Kino et al. was the only study to identify a clear connection between the BZ and the fibrous capsule of the parotid gland.

\section{DISCUSSION}

Study of the BZ began in the 1950s, one of the first authors to describe it being Rees (1954). Subsequently, various investigators have discussed and extended knowledge of the area (Parsons \& Boucher; Kino et al.; Wish-Baratz et al.; Wilkinson \& Crowley; Schmolke; Benigno et al.; Siéssere et al., 2004; Mérida-Velasco et al., 2007). Rees reported that the $A D$ was divided into four zones, the last of which, the BZ, was composed of a superior and an inferior lamina. The PS-JC was identified as an independent structure. In our results, we found four studies that supported the idea of the PS-JC as part of the bilaminar zone (Schmolke; Mérida Velasco et al.; Mérida-Velasco et al., 2007, 2012), while two studies maintained that the PSJC should be considered an independent structure (Wilkinson \& Crowley; Siéssere et al. 2004). Considering the technological progress of recent decades, and the first four studies are more up-to-date, our investigation supports the idea of considering the PS-JC as part of the BZ. However, more investigation is needed in this area as there are few modern studies reporting its exact morphology. 
The traditional literature describes the $\mathrm{BZ}$ as a structure composed of a superior and an inferior lamina with an intermediate zone between them (Manns \& Díaz, 1983; Gómez \& Campos; Okeson). Several of the studies included agree with the description of the traditional literature (Wilkinson \& Crowley; Mérida Velasco et al.; Benigno et al.; Mérida-Velasco et al., 2007), which also agrees with Rees' description of the BZ. However, Shiraishi et al. and Kino et al. support the idea that this area is not composed of laminae, as they report that the principal direction of the fibers is from medial to lateral. Considering the findings of the present study, we suggest that the composition of this area is in fact laminar, as indicated traditionally in the literature.

The fibers of which the BZ is composed have only been described in general terms, for example noting the presence of abundant elastic fibers (Oyanguren et al.; Mérida-Velasco et al., 2012). There are few studies in humans intended to provide a quantitative description of the BZ. The only such studies found in this review were Clément et al. (2006) and Kurita et al., who provide a quantitative analysis of the $\%$ of fibers making up the BZ. It is reported that the BZ contains more elastic fibers than the AD, and that there are more in the superior lamina than the inferior (Wilkinson \& Crowley; Clément et al.). Gómez \& Campos later reported that the inferior lamina is composed exclusively of collagen fibers. More studies are needed in this area to unify the knowledge of professionals, investigators and students.

Descriptions of the vascularization and innervation of the BZ in the literature are consistent. Moreover, many authors recognize the discomalleolar ligament and its close relation with the BZ (Kino et al.; Mérida Velasco et al.; Loughner et al.; Mérida-Velasco et al., 2007; Arai \& Sato; Mérida-Velasco et al., 2012; Anastasi et al.). The discomalleolar ligament could therefore be considered part of the BZ and be described among the structures making up this area.

\section{CONCLUSIONS}

The BZ is of great interest to science, however the literature is still not conclusive in some areas, such as its composition. Further research is required to complement existing knowledge, using reliable methods of analysis like optical, polarized light or sweep electron microscopy, to obtain an accurate quantitative assessment of the number and type of fibers that make up this zone. The PS-JC is considered part of the $\mathrm{BZ}$ and has a laminar structure.
FARFÁN, C.; QUIDEL, B.; BORIE-ECHEVARRÍA, E. \& FUENTES, R. Componentes anatómicos e histológicos de la zona bilaminar de la articulación temporomandibular. Una revisión narrativa. Int. J. Morphol., 39(2):477-483, 2021.

RESUMEN: Una de las estructuras que contribuye al correcto funcionamiento de la Articulación Temporomandibular (ATM) es el Disco Articular (DA). Visto en sección sagital, el DA se divide en cuatro zonas, la última de las cuales es la Zona Bilaminar (BZ). El BZ es esencial para mantener el AD en su posición superior y para retraer el $\mathrm{AD}$ hacia atrás en la posición de máxima apertura. Su composición y disposición de sus componentes no está clara. El objetivo de esta revisión es actualizar conceptos sobre la anatomía del BZ, además de sus variaciones, componentes histológicos, vascularización e inervación. Se revisaron las siguientes bases de datos: PUBMED, SCOPUS, EMBASE, WEB OF SCIENCE, SciELO y LILACS. Se incluyeron estudios en seres humanos sin alteraciones de la ATM, utilizando disección en cadáveres o radiografía en sujetos vivos. Se excluyeron las revisiones sistemáticas, cartas al editor, artículos técnicos y estudios experimentales o cuasi-experimentales en animales. Esta revisión incluyó un total de 24 artículos que correspondían al objeto de investigación propuesto. Nuestros resultados describen la morfología del BZ, sus relaciones anatómicas y posibles variaciones, sus componentes histológicos, tipos de fibras y porcentajes de distribución; estos últimos se discuten en la literatura, pero no existe consenso. Este no es el caso de la vascularización e inervación del BZ; todos los autores analizados coinciden en estos aspectos, y solo un autor agrega dos posibles arterias que pueden tener un papel en la irrigación. Además, un gran número de autores reconocen el ligamento disco maleolar y su estrecha relación con el BZ.

PALABRAS CLAVE: Articulación temporomandibular; Anatomía; Zona bilaminar; Zona retrodiscal; Histología.

\section{REFERENCES}

Anastasi, M. R.; Macchi, V.; Vellone, V.; Siniscalchi, E. N.; Anastasi, G.; Morra, A.; Porzionato, A.; De Caro, R.; De Ponte, F. S. \& Cascone, P. The discomallear ligament: anatomical, microscopical, and radiologic analysis. Surg. Radiol. Anat., 42(5):559-65, 2020.

Arai, H. \& Sato, I. Anatomical study of the human discomallear ligament using cone beam computed tomography imaging and morphological observations. Okajimas Folia Anat. Jpn., 88(3):89-101, 2011.

Ballesteros, L. E. \& León-S, F. E. Estudio anátomo-patológico del disco de la articulación temporomandibular en individuos colombianos. Rev. Med. Chile, 27(12):1469-74, 1999.

Benigno, M.; Azeredo, R.; Lemos, J.; Konig, B. \& Liberti, E. The structure of the bilaminar zone in the human temporomandibular joint: a light and scanning electron microscopy study in young and elderly subjects. J. Oral Rehabil., 28(2):113-9, 2001.

Clément, C.; Bravetti, P.; Plenat, F.; Foliguet, B.; Haddioui, A.; Gaudy, J. \& Weissenbach, M. Quantitative analysis of the elastic fibers in the human temporomandibular articular disc and its attachments. Int. J. Oral Maxillofac. Surg., 35(12):1120-6, 2006.

Coombs, M.; Petersen, J.; Wright, G.; Lu, S.; Damon, B. \& Yao, H Structure-Function Relationships of Temporomandibular Retrodiscal Tissue. J. Dent. Res., 96(6):647-53, 2017. 
Decuadro-Sáenz, G.; Castro, G.; Sorrenti, N.; Doassans, I.; Deleon S.; Salle, F.; Saibene, A.; Santamaría, A.; Pérez-Brignani A. \& Soria-Vargas, V. Auriculo temporal nerve. Neuroanatomic bases of the Frey' Syndrome. Neurocirugia (Astur), 19(3):218-32, 2008.

Eder, J.; Tonar, Z.; Schmid-Schwap, M.; Bristela, M.; Skolka, A.; Traxler, H.; Piehslinger, E.; Egerbacher, M.; Trattnig, S. \& Witter, K. Regional collagen fiber network in the articular disc of the human temporomandibular joint: biochemical 3-tesla quantitative magnetic resonance imaging compared to quantitative histologic analysis of fiber arrangement. J. Oral Facial Pain Headache, 32(3):266-76, 2018.

Farfán, C.; Quidel, B. \& Fuentes, R. Anatomical functional characteristics that guide the condylar position in mandibular fossa a centric relation. narrative description. Int. J. Morphol., 38(5):1281-7, 2020.

Fuentes, R. \& Ottone, N. E. Proposal on inclusion and elimination of anatomical terms in Terminologia Anatomica corresponding to the temporomandibular joint. Int. J. Morphol., 35(1):12-5, 2017.

Fuentes, R.; Ottone, N. E.; Bucchi, C. \& Cantín, M. Analysis of terms used in the literature to refer to temporomandibular joint capsule and joint ligaments. Int. J. Morphol., 34(1):342-50, 2016a.

Fuentes, R.; Ottone, N. E.; Saravia, D. \& Bucchi, C. Irrigation and innervation of the temporomandibular joint. A literature review. Int. J. Morphol., 34(3):1024-33, 2016b.

Gómez, M. \& Campos, A. Histología, Embriología, e Ingeniería Tisular Bucodental. $3^{\mathrm{a}}$ ed. Buenos Aires, Médica Panamericana, 2009.

Grau, L.; Fernández, K.; González, G. \& Osorio, M. Algunas consideraciones sobre los trastornos temporomandibulares. Rev Cuba. Estomatol., 42(3), 2005. Disponible en: http://scielo.sld.cu/scielo.php?script= sci_arttext\&pid=S0034-75072005000300005\&lng=es\&nrm=iso >. ISSN 0034-7507

Helmy, E. S.; Timmis, D. P.; Sharawy, M. H.; Abdelatif, O. \& Bays, R. A. Fatty change in the human temporomandibular joint disc. Light and electron microscopy study. Int. J. Oral Maxillofac. Surg., 19(1):38-43, 1990.

Kino, K.; Ohmura, Y. \& Amagasa, T. Reconsideration of the bilaminar zone in the retrodiskal area of the temporomandibular joint. Oral Surg. Oral Med. Oral Pathol., 75(4):410-21, 1993.

Kurita, K.; Westesson, P. L.; Sternby, N. H.; Eriksson, L.; Carlsson, L. E.; Lundh, H. \& Toremalm, N. G. Histologic features of the temporomandibular joint disk and posterior disk attachment: comparison of symptom-free persons with normally positioned disks and patients with internal derangement. Oral Surg. Oral Med. Oral Pathol., 67(6):635-43, 1989.

Leonardi, R.; Rusu, M. C.; Loreto, F.; Loreto, C. \& Musumeci, G. Immunolocalization and expression of lubricin in the bilaminar zone of the human temporomandibular joint disc. Acta Histochem., 114(1):1$5,2012$.

Loughner, B. A.; Gremillion, H. A.; Mahan, P. E. \& Watson, R. E. The medial capsule of the human temporomandibular joint. J. Oral Maxillofac. Surg., 55(4):363-9, 1997.

Mackinnon, P. \& Morris, J. Oxford Anatomía Funcional. Cabeza y Cuello. Volumen III. Bogotá, Médica Panamericana, 1993.

Manns, A. \& Díaz, G. Sistema Estomatognático. Santiago de Chile, Empigraf, 1983.

Matamala, V. F.; Fuentes, F. R. \& Ceballos, C. M. Morphology and morphometry of the temporomandibular joint disc in human fetus and adults. Int. J. Morphol., 24(2):245-50, 2006.

Mérida Velasco, J. R.; Rodríguez Vásquez, J. F. \& Jimenez Collado, J. Anterior tympanic artery: course, ramification and relationship with the temporomandibular joint. Acta Anat. (Basel), 158(3):222-6, 1997.

Mérida-Velasco, J. R.; de la Cuadra-Blanco, C.; Pozo Kreilinger, J. J. \& Mérida-Velasco, J. A. Histological study of the extratympanic portion of the discomallear ligament in adult humans: a functional hypothesis. J. Anat., 220(1):86-91, 2012.

Mérida-Velasco, J. R.; Rodríguez, J. F.; de la Cuadra, C.; Peces, M. D.; Mérida, J. A. \& Sánchez, I. The posterior segment of the temporomandibular joint capsule and its anatomic relationship. J. Oral Maxillofac. Surg., 65(1):30-3, 2007.
Ohta, Y.; Suwa, F.; Yang, L.; Wang, M. \& Wang, H. Development and histology of fibrous architecture of the fetal temporomandibular joint. Okajimas Folia Anat. Jpn., 70(1):1-5, 1993.

Okeson, J. P. Tratamiento de Oclusión y Afecciones Temporomandibulares. $7^{\mathrm{a}}$ ed. Barcelona, Elsevier, 2013.

Oyanguren, F. R.; Wurgaft, D. R. \& Montenegro, R. M. A. Histologicaland histochemical evaluation of collagen and elastic fibers in human TMJ tissue. Int. J. Odontostomat., 4(3):277-84, 2010.

Paegle, D. I.; Holmlund, A. B. \& Reinholt, F. P. Characterization of tissue components in the temporomandibular joint disc and posterior disc attachment region: internal derangement and control autopsy specimens compared by morphometry. J. Oral Maxillofac. Surg., 60(9):1032-7, 2002.

Parsons, M. T \& Boucher, L. J. The bilaminar zone of the meniscus. $J$. Dent. Res., 45(1):59-61, 1966.

Pertes, R. \& Gross, S. Tratamento Clínico das Disfunçoes Temporomandibulares e da Dor Orofacial. São Paulo, Quintessence, 2005.

Rees, L. A. The structure and function of the mandibular joint. Br. Dent. J., 96(6):125-33, 1954.

Sakuma, K.; Sano, T.; Yamamoto, M.; Tachikawa, T. \& Okano, T. Does decreased $\mathrm{T} 1$ signal intensity in the retrodiscal tissue of the temporomandibular joint reflect increased density of collagen fibres? Dentomaxillofac. Radiol., 32(4):222-8, 2003.

Schmolke, C. The relationship between the temporomandibular joint capsule, articular disc and jaw muscles. J. Anat., 184(Pt. 2):335-45, 1994.

Shiraishi, Y.; Hayakawa, M.; Tanaha, S. \& Hoshino, T. A new retinacular ligament and vein of the human temporomandibular joint. Clin. Anat., 8(3):208-13, 1995.

Siéssere, S.; Vitti, M.; Semprini, M.; Regalo, S. C. H.; Iyomasa, M. M.; Dias, F. J.; Issa, J. P. M. \& de Sousa, L. G. Macroscopic and microscopic aspects of the temporomandibular joint related to its clinical implication. Micron, 39(7):852-8, 2008.

Siéssere, S.; Vitti, M.; Souza, L.; Semprini, M. \& Regalo, S. Bilaminar zone: anatomical aspects, irrigation and innervations. Braz. J. Morphol. Sci., 21(4):217-20, 2004.

Urrútia, G. \& Bonfill, X. PRISMA declaration: a proposal to improve the publication of systematic reviews and meta-analyses. Med. Clin. (Barc.), 135(11):507-11, 2010.

Wilkinson, T. M. \& Crowley, C. M. A histologic study of retrodiscal tissues of the human temporomandibular joint in the open and closed position. J. Orofac. Pain, 8(1):7-17, 1994.

Wish-Baratz, S.; Ring, G. D.; Hiss, J.; Shatz, A. \& Arensburg, B. The microscopic structure and function of the vascular retrodiscal pad of the human temporomandibular joint. Arch. Oral Biol., 38(3):265-8, 1993.

Yang, L.; Wang, H.; Wang, M.; Ohta, Y. \& Suwa, F. Development of collagen fibers and vasculature of the fetal TMJ. Okajimas Folia Anat. Jpn., 69(4):145-55, 1992.

\section{Corresponding author:}

Prof. Dr. Ramón Fuentes Fernández

Research Centre for Dental Sciences

Dental School, Universidad de La Frontera

Av. Francisco Salazar 1145

Temuco - CHILE

\section{Email: ramon.fuentes@ufrontera.cl}

Received: 27-11-2020

Accepted : 29-12-2020 